University of Nebraska - Lincoln

DigitalCommons@University of Nebraska - Lincoln

7-1-2008

\title{
The Potential for Crop-to-Wild Gene Flow in Sorghum in Ethiopia and Niger: A Geographic Survey
}

\author{
Tesfaye Tesso \\ Ethiopian Institute of Agricultural Research \\ Issoufou Kapran \\ Institut National de la Recherche Agronomique du Niger (INRAN) BP 429, Niamey, Niger \\ Cecile Grenier \\ Purdue University \\ Allison Snow \\ Ohio State University \\ Patricia Sweeney \\ Ohio State University
}

See next page for additional authors

Follow this and additional works at: https://digitalcommons.unl.edu/usdaarsfacpub

Part of the Agricultural Science Commons

Tesso, Tesfaye; Kapran, Issoufou; Grenier, Cecile; Snow, Allison; Sweeney, Patricia; Pedersen, Jeffrey F.; Marx, David B.; Bothma, Gurling; and Ejeta, Gebisa, "The Potential for Crop-to-Wild Gene Flow in Sorghum in Ethiopia and Niger: A Geographic Survey" (2008). Publications from USDA-ARS / UNL Faculty. 211. https://digitalcommons.unl.edu/usdaarsfacpub/211

This Article is brought to you for free and open access by the U.S. Department of Agriculture: Agricultural Research Service, Lincoln, Nebraska at DigitalCommons@University of Nebraska - Lincoln. It has been accepted for inclusion in Publications from USDA-ARS / UNL Faculty by an authorized administrator of DigitalCommons@University of Nebraska - Lincoln. 


\section{Authors}

Tesfaye Tesso, Issoufou Kapran, Cecile Grenier, Allison Snow, Patricia Sweeney, Jeffrey F. Pedersen, David B. Marx, Gurling Bothma, and Gebisa Ejeta 


\title{
The Potential for Crop-to-Wild Gene Flow in Sorghum in Ethiopia and Niger: A Geographic Survey
}

\author{
Tesfaye Tesso, Issoufou Kapran, Cécile Grenier, Allison Snow, \\ Patricia Sweeney, Jeff Pedersen, David Marx, Gurling Bothma, and Gebisa Ejeta^
}

\begin{abstract}
Information about the potential for crop-wild hybridization is needed to understand how crop genes, including transgenes, affect the population genetics and ecology of sexually compatible relatives. Transgenic sorghum is under development for use by traditional farmers in Africa, the center of origin for sorghum [Sorghum bicolor (L.) Moench], but systematic surveys of the current extent of contact with wild and weedy relatives are lacking. We studied wild and weedy sorghums that are interfertile with the crop and constitute a crop-wild-weed complex. The survey was conducted in 2005 in areas of traditional sorghum cultivation in three regions of Ethiopia and two regions of Niger. Within each region, we examined eight representative sorghum fields at each of 10 locations during peak flowering of the crop. In all regions, wild and weedy sorghum occurred intermixed with and adjacent to cultivated sorghum. Wild and weedy sorghums were detected at 56,44 , and $13 \%$ of the Ethiopian sites (Amhara, Tigray, and Hararghe regions, respectively), and 74 and 63\% of sites in Niger (Maradi-Tahoua and TillaberyDosso regions, respectively). Flowering periods of wild and weedy sorghum populations overlapped with those of cultivated sorghum at most sites where the two co-occurred, especially in Ethiopia, and many putative crop-wild hybrids were observed. Therefore, current gene transfer from cultivated sorghum to wild and weedy sorghum populations in Ethiopia and Niger is likely to be widespread.
\end{abstract}

T. Tesso, Ethiopian Institute of Agricultural Research, P.O. Box 436, Nazareth, Ethiopia; I. Kapran, Institut National de la Recherche Agronomique du Niger (INRAN) BP 429, Niamey, Niger; C. Grenier and G. Ejeta, Dep. of Agronomy, Purdue Univ., West Lafayette, IN 47907; A. Snow and P. Sweeney, Dep. of Evolution, Ecology and Organismal Biology, Ohio State Univ., Columbus, OH 43210; J. Pedersen and D. Marx, USDA-ARS, Grain, Forage, and Bioenergy Research, Univ. of Nebraska, Lincoln, NE 68583 and Dep. Statistics, Univ. of Nebraska, Lincoln, NE 68583; G. Bothma, Agricultural Research Council, Vegetable and Ornamental Plant Institute, Private Bag X293, Pretoria, South Africa. Received 10 Aug. 2007. ^Corresponding author (gejeta@purdue.edu).

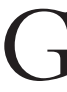
ENE EXCHANGE has been one of the major factors in the Jevolution of domesticated plant species (Harlan, 1992). Many cultivated species hybridize spontaneously with their wild and weedy relatives and produce fertile hybrids (e.g., Wilkes, 1977; Doebley, 1990; Paterson et al., 1995; Hauser and Bjarn, 2001; Zaharieva and Monneveux, 2006). Naturally occurring hybridization has been reported between wild relatives and economically important crops such as wheat (Triticum aestivum L.), sorghum [Sorghum bicolor (L.) Moench], rice (Oryza sativa L.), sunflower (Helianthus annuus L.), canola (Brassica napus L.), and squash (Cucurbita pepo L.) (e.g., Ellstrand et al., 1999; Giddings, 2000; Jenczewski et al., 2003). Plant breeders often use wild germplasm to obtain useful agronomic traits (e.g., Rick et al., 1987; Baum et al., 1992; Fedak and Han, 2005), but these artificial crosses do not indicate whether spontaneous hybridization is common under field conditions.

Many cultivated species are highly domesticated and their survival potential without human assistance is relatively low. In

Published in Crop Sci. 48:1425-1431 (2008)

doi: 10.2135/cropsci2007.08.0441

(C) Crop Science Society of America

677 S. Segoe Rd., Madison, WI 53711 USA

All rights reserved. No part of this periodical may be reproduced or transmitted in any form or by any means, electronic or mechanical, including photocopying, recording, or any information storage and retrieval system, without permission in writing from the publisher. Permission for printing and for reprinting the material contained herein has been obtained by the publisher. 
some cases, however, crop volunteers can persist as feral populations, especially if the crop has hybridized with a wild relative or is not fully domesticated (e.g., Gressel, 2005; Reagon and Snow, 2006). Wild genes may persist in crop populations only if their effects are neutral, if they confer fitness benefits to the crop, or if they confer agronomic traits that are desired by farmers. Genes that spontaneously disperse from cultivated plants into populations of wild, weedy, or feral relatives have a better chance of persistence in the ecosystem, provided that they are not detrimental to the survival of the plant in its natural environment.

Over the last 10 years, crop-to-wild gene flow has received considerable attention because of its implications for the development and deployment of transgenic crops. In some cases, transgenes that introgress into wild populations could promote the evolution of more aggressive weeds that are better adapted to artificial or natural habitats (Ellstrand and Hoffman, 1990; Snow et al., 2003). For example, novel alleles that enhance resistance to pests and pathogens and/or increase tolerance to abiotic stresses could confer a competitive advantage to individuals receiving these alleles, which in turn could impact the size and dynamics of the wild or weedy populations (Snow et al., 2003). Another concern about crop-to-wild gene flow, regardless of whether the crop is transgenic, is that overwhelming gene flow from the crop could displace the native gene pool of threatened and endangered wild relatives, resulting in a loss of genetic diversity (e.g., Akimoto et al., 1999). Thus, information about the extent of crop-to-wild gene flow is needed when populations of wild relatives are declining, as well as for standard risk assessments of transgenic crops.

Sorghum is an economically important crop in Africa and many other regions worldwide. Evidence for hybridization between cultivated sorghum and various species of wild sorghum has been reported under experimental conditions (e.g., Sangduen and Hanna, 1984; Paterson et al., 1995; Arriola and Ellstrand, 1996). Crop-specific alleles have been detected in progeny of johnsongrass [S. halepense (L.) Pers.] planted as far as $100 \mathrm{~m}$ from cultivated sorghum, and $F_{1}$ hybrids can have similar fitness to their wild parent (Arriola and Ellstrand, 1996, 1997). Other studies also show genetic and/or morphological evidence for crop-towild gene flow in sorghum (Doggett, 1988, 1991; Harlan, 1992; Aldrich and Doebley, 1992; Aldrich et al., 1992; Morrell et al., 2005). However, the amount of crop pollen required to produce detectable hybridization frequencies varies with population size and distance between the crop and the surrounding wild species (Arriola, 1995; Arriola and Ellstrand, 1996), and little information is available about the current frequency of contact between wild and cultivated sorghum in African agroecosystems.

Wild sorghums with diverse morpho-types have been reported in many of the sorghum-growing regions of Africa, often as indistinct races of S. bicolor that form a crop-wild-weed complex (de Wet 1978; Ejeta and Grenier, 2005). De Wet (1978) recognized a wild subspecies, S. bicolor ssp. arundinaceum (Desv.) de Wet and Harlan, with four races (verticilliflorum, virgatum, aethiopicum, arundinaceum). He also described a weedy subspecies, S. bicolor ssp. drummondii (Nees ex Steud.) de Wet and Harlan, as a possible hybrid between the crop and subspecies arundinaceum. These wild and weedy taxa occur as weeds in fields planted with cultivated sorghum and other crops, in ditches, on fallow land, and along roadsides. Also, the noxious perennial weed johnsongrass has spread to certain warm-temperate areas of Africa (Holm et al., 1977). In contrast, some wild relatives of the crop may be threatened with extinction due to increasing human populations and loss of habitat. For example, Ayana et al. (2000) reported that populations of S. bicolor ssp. arundinaceum, race verticilliflorum, appear to be declining rapidly in western Ethiopia.

Although the mere presence of cultivated species and wild relatives in a given area does not necessarily imply gene flow (Eber et al., 1994; Jenczewski et al., 2003), long-term coexistence in a given habitat may signal the need to assess the likelihood of spontaneous gene transfer from cultivated to wild sorghums. In addition, factors such as sexual compatibility of the species, flowering synchrony, outcrossing rates of wild relatives, proximity to pollen sources, and the persistence of new alleles in recipient populations are among important considerations for documenting effective and persistent gene flow (Keeler and Turner, 1990; Ellstrand et al., 1999; Burke et al., 2002). With regard to sexual compatibility, the wild S. bicolor subspecies and races in Africa are fully interfertile with cultivated sorghum (de Wet, 1978).

Although interference of phenolics in sorghum with callus development and differentiation during the process of transformation has slowed early efforts to generate transgenes in the crop, significant progress has recently been made in optimization of sorghum transformation protocols. Optimum protocols for sorghum transformation have been developed for both agro-bacterium and particle bombardment methods (Casas et al., 1993, 1997; Howe et al., 2006; Gao et al., 2005; Zhao et al., 2000). Chitinase gene coding for antifungal protein, Bt gene, and the high lysine analog (HT12 protein) of barley (Hordeum vulgare L.) alpha-hordothionin protein has been successfully engineered into sorghum plant to enhance resistance to stalk rot disease and stem borer and to improve lysine content, respectively (Krishnaveni et al., 2001; Zhu et al., 1998; Girijashankar et al., 2005; Zhao et al., 2000). More recently, the African Biofortified Sorghum (ABS) Project, funded by the Bill \& Melinda Gates Foundation has embarked on a major initiative to engineer genes encoding for the essential amino acid (lysine), micronutrient (iron, 
zinc) accumulation, and synthesis of vitamin-A precursers into African sorghums to deploy nutritionally enhanced transgenic sorghums to subsistence farmers in the continent (Bean and Ioerger, 2006).

Ethiopia and Niger are among the largest sorghum-producing countries in eastern and western Africa, respectively, and endowed with abundant genetic diversity of the crop. A great deal of diverse cultivated, wild, and weedy morphotypes of S. bicolor, including feral, hybrid, and introgressed genotypes, are prevalent in both east and west Africa.

The study was conducted (i) to assess the potential for pollen-mediated gene transfer from cultivated sorghum to wild and weedy relatives in the two representative sorghum-growing countries of Africa, Ethiopia, and Niger; (ii) to record the prevalence of co-occurring crop and wild and weedy taxa and the extent of overlapping flowering periods under current agricultural production systems in the two countries.

\section{MATERIALS AND METHODS Study Sites}

Field surveys were performed in three sorghum-growing regions of Ethiopia (Amhara, Tigray, and Hararghe zones in Oromia) and two regions of Niger (Maradi-Tahoua and Tillabery-Dosso). Geographical characteristics of the study regions and survey routes are shown in Table 1 and Fig. 1. The regions represent major sorghum crop ecosystems in the center of origin for the crop, with a variety of landraces grown in different zones. In both countries, sorghum production is largely performed using manual labor, no irrigation, and few chemical inputs to enhance plant nutrition and protect against weeds, pests, and diseases (e.g., Pandey et al., 2001). Use of improved seed is also limited, as farmers typically save grain from their crop fields to use as seed for the next crop.

In Ethiopia, the study areas in Tigray and much of the Amhara region are characterized by severely degraded soil fertility and low annual rainfall $(400-850 \mathrm{~mm})$ that is unevenly distributed during the year. Sorghum is a staple crop in the

Table 1. Geographical and climatic characteristics and area cultivated to sorghum in the surveyed regions in Ethiopia and Niger.

\begin{tabular}{llccccc}
\hline Country & \multicolumn{1}{c}{ Region } & Latitude & Longitude & Altitude & Annual precipitation ${ }^{\dagger}$ & Area under sorghum cultivation $^{\ddagger}$ \\
\hline \multirow{6}{*}{ Ethiopia } & & & & $\mathrm{masl}$ & $\mathrm{mm}$ & $\%$ \\
& Amhara & $10^{\circ} 00-12^{\circ} 20 \mathrm{~N}$ & $39^{\circ} 29-40^{\circ} 02 \mathrm{E}$ & $1145-2358$ & $400-750$ & 30.3 \\
& Hararghe & $8^{\circ} 27-9^{\circ} 28 \mathrm{~N}$ & $40^{\circ} 19-42^{\circ} 36 \mathrm{E}$ & $1312-2161$ & $450-850$ & 59.7 \\
\multirow{2}{*}{ Niger } & Tigray & $12^{\circ} 23-14^{\circ} 27 \mathrm{~N}$ & $36^{\circ} 37-39^{\circ} 41 \mathrm{E}$ & $623-2161$ & $400-600$ & - \\
& Maradi-Tahoua & $13^{\circ} 05-14^{\circ} 33 \mathrm{~N}$ & $04^{\circ} 47-07^{\circ} 15 \mathrm{E}$ & $260-437$ & $250-500$ & - \\
\hline
\end{tabular}

${ }^{\dagger}$ Data from National Meteorological Services Agency (1996).

‡Data from Central Statistical Authority (2004).

\section{LEGEND}

\section{○ No Wild \\ - Wild species}
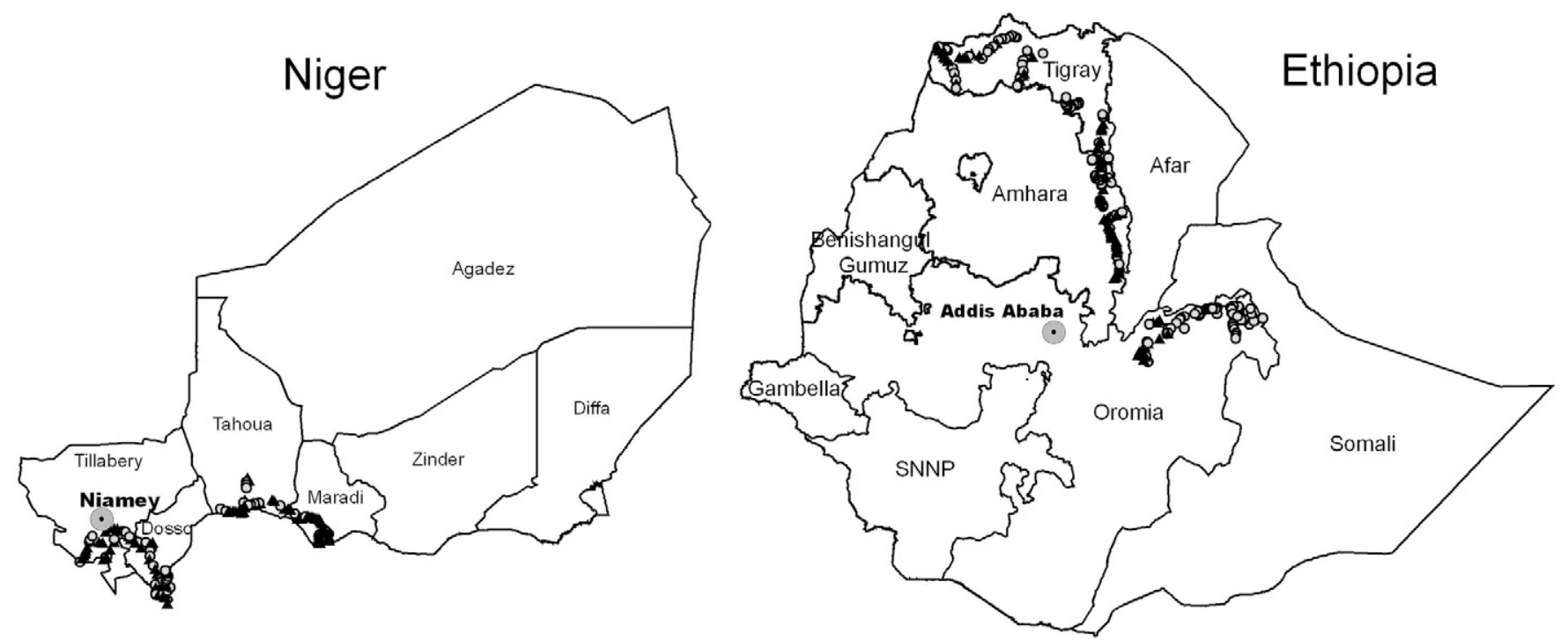

Figure 1. The survey sites in Ethiopia and Niger and occurrence of wild sorghum populations. Survey was conducted in parts of Amhara, Tigray, and Oromia administrative regions of Ethiopia, and the Maradi-Tahoua, and Tillabery-Dosso regions in Niger during the crop season of 2005. 
study areas of both regions, with the largest proportion of land under cereal cultivation allotted to this crop annually (Central Statistical Authority, 2004). Most producers are subsistence farmers with farm sizes ranging from less than half a hectare to one hectare. Both regions represent major local centers of sorghum diversity. The Hararghe region in Oromia is located in eastern Ethiopia, where rainfall averages 450 to $850 \mathrm{~mm}$ annually. Approximately half of this region is in sorghum cultivation and nearly half of sorghum is intercropped with other crops, mainly haricot beans [Phaseolus vulgaris (L.) Walp.], groundnut (Arachis hypogaea L.), and chat [Chata edulis (Vahl) Forsk. ex Endl.], a shrub used as a stimulant that has fast become the dominant cash crop in the region. Population pressure in the area is extremely high, with little or no land left unplanted or available for grazing livestock. As a result, unlike other regions where sorghum is grown exclusively for food, use of fodder and stover for animal feed is a major consideration of sorghum production in Hararghe. Farmers usually begin their sorghum husbandry with normal or slightly above normal densities of crop plants and later thin out extra seedlings and weeds to feed to livestock.

In Niger, crop agriculture is concentrated in the south because the northern area of the country is mainly desert $(<100$ $\mathrm{mm}$ of precipitation annually) occupied by nomadic livestock herders. One of the two southern regions we surveyed is Maradi-Tahoua, consisting of the Maradi and Tahoua administrative areas. Agriculture in these areas is predominantly rain fed and intercropping of two to five species is often practiced. The region is characterized by low annual rainfall $(250-500 \mathrm{~mm})$ and poor soil fertility. Pearl millet [Pennisetum glaucum (L.) R. Br.] is the most important food crop, followed by grain sorghum and two leguminous cash crops, cowpea [Vigna unguiculata (L.) Walp.] and groundnut. The Tillabery-Dosso survey region is located in the southwestern Sudano-Sahelian zone, where average annual rainfall is 500 to $800 \mathrm{~mm}$. Soils are better in fertility and texture than in Maradi-Tahoua, especially along the Niger River Valley where much of the survey took place. There is a striking contrast in sorghum races cultivated in the survey regions, with predominance of guinea sorghums in Tillabery-Dosso and caudatum and durra races more prevalent in Maradi-Tahoua.

\section{Sampling Methods and Analyses}

For the field surveys, we selected 10 locations identified by physical landmarks and town centers within each region. The survey was conducted at peak sorghum flowering time during late September and early October 2005. In each location, eight random stops were made at sorghum fields of at least onequarter hectare in size and separated from each other by at least $5 \mathrm{~km}$, for a total of 80 study sites per region. At one location, in Hararghe, we were able to sample only seven sites, rather than eight. At each site, observations of wild sorghum were made inside the sorghum field and within a $0.5-\mathrm{km}$ radius from the field. We recorded the latitude, longitude, and elevation of each site using a handheld global positioning system (GPS) device, the presence or absence of wild sorghum species at the site, and whether the wild species occurred intermixed with the crop and/or away from crop field and within $0.5 \mathrm{~km}$. Flowering synchrony between wild and cultivated sorghum was recorded at each site, except for 14 sites in Niger where these data were not obtained. Global positioning system data and presence-absence data for all study sites are available online as Supplementary Table 1. A larger survey of the geographic distribution of wild sorghum populations in other types of habitats was beyond the scope of the present study.

Data were organized in binary sets (present or absent) and were analyzed using PROC GLIMMIX model of the Statistical Analysis Systems software (SAS Institute, 2005) to compare regions within countries. In the model, the survey regions were considered as fixed effects and location within a region as a random effect. For each region, the proportions of positive responses for each variable were estimated and a 95\% confidence interval for these proportions determined. The $P$-values were estimated to determine the significance of observed differences for the variables shown in Table 2.

\section{RESULTS AND DISCUSSION Distribution of Wild Relatives}

Wild sorghum plants were found growing in and around sorghum crop fields in all regions of the two countries. Although we did not attempt to identify different wild subspecies, we observed a great deal of phenotypic

Table 2. Mean proportions of cultivated sorghum fields with wild sorghum present and extent of overlapping flowering times of wild and cultivated sorghum in major sorghum-producing regions of Ethiopia and Niger.

\begin{tabular}{|c|c|c|c|c|c|c|c|}
\hline \multirow{2}{*}{ Crop-wild association } & \multicolumn{4}{|c|}{ Ethiopia } & \multicolumn{3}{|c|}{ Niger } \\
\hline & Amhara & Tigray & Hararghe & $P$ value & Maradi-Tahoua & Tillabery-Dosso & $P$ value \\
\hline Presence of wild ${ }^{\dagger}$ & $\begin{array}{l}0.56 \\
(0.32-0.77)^{\ddagger}\end{array}$ & $\begin{array}{l}0.44 \\
(0.22-0.68)\end{array}$ & $\begin{array}{l}0.13 \\
(0.04-0.31)\end{array}$ & 0.021 & $\begin{array}{l}0.74 \\
(0.61-0.84)\end{array}$ & $\begin{array}{l}0.63 \\
(0.49-0.75)\end{array}$ & 0.193 \\
\hline Wild intermixed with crop ${ }^{\dagger}$ & $\begin{array}{l}0.33 \\
(0.17-0.54)\end{array}$ & $\begin{array}{l}0.36 \\
(0.19-0.57)\end{array}$ & $\begin{array}{l}0.07 \\
(0.03-0.19)\end{array}$ & 0.019 & $\begin{array}{l}0.49 \\
(0.40-0.64)\end{array}$ & $\begin{array}{l}0.56 \\
(0.44-0.68)\end{array}$ & 0.411 \\
\hline Wild growing near $\mathrm{crop}^{\dagger}$ & $\begin{array}{l}0.30 \\
(0.16-0.49)\end{array}$ & $\begin{array}{l}0.12 \\
(0.05-0.25)\end{array}$ & $\begin{array}{l}0.09 \\
(0.03-0.20)\end{array}$ & 0.040 & $\begin{array}{l}0.70 \\
(0.52-0.81)\end{array}$ & $\begin{array}{l}0.58 \\
(0.42-0.72)\end{array}$ & 0.245 \\
\hline Flowering synchrony (all fields) $)^{\dagger}$ & $\begin{array}{l}0.52 \\
(0.29-0.74)\end{array}$ & $\begin{array}{l}0.44 \\
(0.23-0.66)\end{array}$ & $\begin{array}{l}0.13 \\
(0.05-0.31)\end{array}$ & 0.029 & $\begin{array}{l}0.37 \\
(0.21-0.57)\end{array}$ & $\begin{array}{l}0.18 \\
(0.08-0.34)\end{array}$ & 0.095 \\
\hline $\begin{array}{l}\text { Flowering synchrony where wild } \\
\text { sorghum was present } \$\end{array}$ & $\begin{array}{l}0.93 \\
(N=44)\end{array}$ & $\begin{array}{l}1.00 \\
(N=35)\end{array}$ & $\begin{array}{l}1.00 \\
(N=15)\end{array}$ & - & $\begin{array}{l}0.55 \\
(N=47)\end{array}$ & $\begin{array}{l}0.31 \\
(N=48)\end{array}$ & - \\
\hline
\end{tabular}

tSample size $(N)=10$ locations per region with eight sample sites per location.

łNumbers in parenthesis are 95\% confidence intervals for average proportions.

$\S$ Sample size $(N)$ is the number of sites with wild sorghum plants present, pooled from all sites within each region. 
diversity within regions, locations, and individual fields. A subset of the great morphological diversity of wild and weedy sorghum types typically found at a single farmer's field in Ethiopia is shown in Fig. 2.

Phenotypic characteristics of the wild relatives appeared to vary according to habitat and proximity to cultivated sorghum, perhaps reflecting past hybridization and the resultant introgression with the crop. Wild plants that had relatively small stature, thin culm, and very loose panicles were mostly found in ruderal areas such as roadsides, abandoned fields, crop margins, and unweeded crop fields, or occasionally intermixed with cultivated crops. In contrast, wild plants with a closer resemblance to cultivated sorghum occurred mainly in crop habitats and were often intermixed with sorghum as well as other crops. It is not clear whether these associations are due to differences in the extent of crop-wild hybridization, adaptation of the different wild-types to different habitats, or human interference via selective roguing, for example. Further studies of the ecology, population genetics, and phylogeography of these taxa are needed to investigate their status as agronomic weeds, or the extent to which they are sustained as genetically diverse germplasm for continuous breeding.

Wild sorghum was very common in all of the sampled regions, with the exception of Hararghe in Ethiopia, where only $13 \%$ of the surveyed sites had wild species (Table 2). In the Amhara and Tigray regions of Ethiopia, wild sorghum was reported in 56 and $44 \%$ of the surveyed fields, respectively. The proportion of fields with wild species present was significantly different among these three regions of Ethiopia. In Niger, wild sorghum was detected in 74 and $63 \%$ of the sites in Maradi-Tahoua and Tillabery-Dosso, respectively, and the difference between the two regions was not significant (Table 2).

The significant variation in the frequency of wild sorghum among regions in Ethiopia may be attributable to a combination of factors. The difference in the amount of wild seed inoculum originally present in the soils of the different regions may be an important factor. Also, differences in agricultural practices among regions may have resulted in either depletion or build-up of seed inoculum of wild species (Ejeta and Grenier, 2005). The Hararghe region, for instance, is characterized by high population density and heavy land pressure. Weeds including wild sorghums typically are cleared from crop fields by hand and fed to animals, and only those wild sorghums that are difficult to distinguish from cultivated types at vegetative stage are left to grow through flowering. Even those have a rare chance of surviving to maturity as farmers aggressively search for fodder for animal feed and often are forced to remove or defoliate even the main sorghum crop. In the other study regions, farming pressure appears to be less severe and crop fields may be weeded less frequently, giving wild and weedy species a better chance of
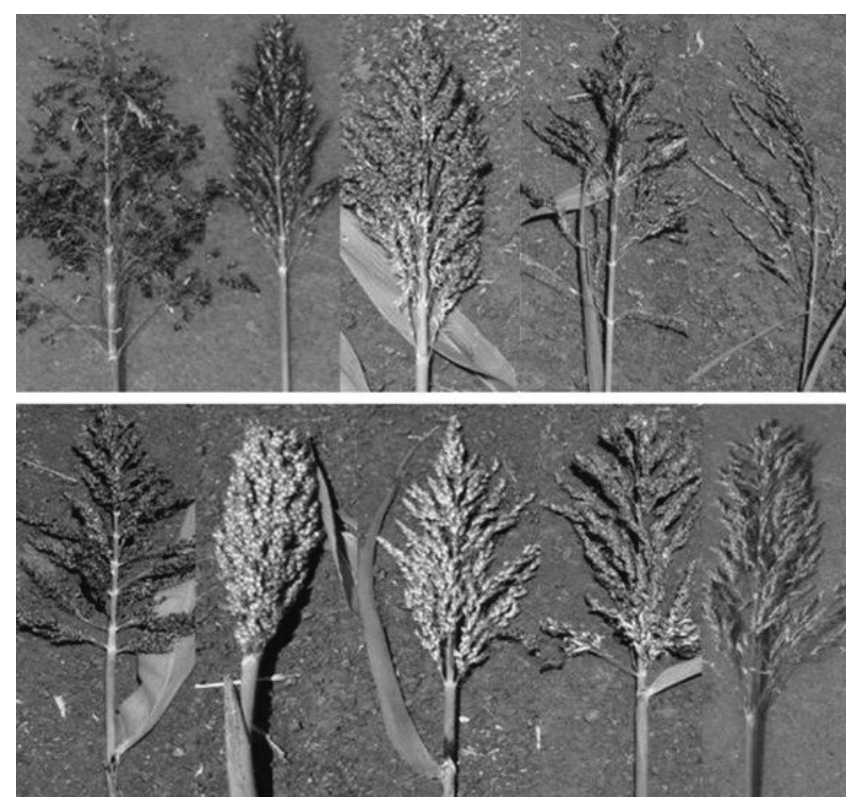

Figure 2. Examples of morphological diversity of wild sorghum types detected in single sorghum field in Wollo, Ethiopia.

growing to maturity. In Ethiopia, we also observed that the distribution of wild-types within an area seems to be influenced by topography. Wild sorghum tends to be most prevalent in low-lying and hill bottom areas.

The proximity of wild species in relation to the cultivated crop has important implications for gene flow (Ellstrand et al., 1999). In the two regions of Niger, wild species were found intermixed with the crop in 49 and $56 \%$ of the sampled sites (Table 2; differences between regions were not significant). In Ethiopia, regional differences in the proportions of sites with intermixed wild and crop plants were significant, reflecting differences in the overall presence or absence of wild species, as described above. Intermixing was much lower in Hararghe region (7\%) compared to Amhara (33\%) and Tigray (36\%). This was probably because in Hararghe very few plots were left unplanted and in most of these areas the fields were repeatedly weeded or grazed so that there was little or no chance of wild and weedy sorghum growing to flowering and maturity.

Another variable we measured was the proportion of sites where wild sorghum occurred within $0.5 \mathrm{~km}$ of the selected crop field. Wild sorghum occurred within this radius at 9 to $30 \%$ of sites in the three study regions of Ethiopia and 58 to $70 \%$ of sites in the two regions of Niger (Table 2). These plants occurred in fallow lands, crop margins, other crop fields, and in crops that were abandoned due to severe drought, pests and weeds, or extreme nutrient deficiency. This suggests that wild sorghums possess characteristics that allow them to continue to prevail in major sorghum-growing regions. It is likely that some of the wild sorghum plants within $0.5 \mathrm{~km}$ of the crop could be pollinated by crop pollen, which is expected 
to disperse $\sim 100$ to $700 \mathrm{~m}$ from its source (Arriola and Ellstrand, 1996; Schmidt and Bothma, 2006). Also seeds from these wild plants could disperse into nearby sorghum crops, facilitating crop-to-wild gene flow in other seasons. In addition, areas with wild sorghum in the seed bank could also be converted to sorghum cultivation in future seasons. In summary, our single-season survey of five major sorghum-producing regions shows that wild species often co-occur with the crop, either intermixed with crop plants or in adjacent habitats.

\section{Flowering Synchrony between Cultivated Sorghum and Wild and Weedy Relatives}

In addition to occurrence and distribution, the timing of flowering of the wild sorghum species in relation to the cultivated crop is an important consideration in assessing the potential for gene flow. In Ethiopia, the flowering times of wild and cultivated sorghum overlapped at more than $90 \%$ of the study sites where wild sorghum was present (Table 2). In Niger, overlapping flowering periods were observed for $55 \%$ of the sites with wild sorghum in Maradi-Tahoua, and 31\% of the sites in Tillabery-Dosso. These frequencies are clearly high enough to permit gene flow between wild sorghum and the crop. Reasons for less overlap of flowering phenology in Niger are not known. Factors such as differences in cultural practices, types of cultivars grown, and characteristics of the wild sorghum types may be responsible. In Tillabery-Dosso, for instance, farmers grow landraces that mature later than most of the wild sorghum types.

\section{CONCLUSIONS}

This study indicates that there is potential for crop genes to introgress into populations of wild relatives of sorghum under the existing sorghum production practices in Africa. The primary conditions for spontaneous hybridization, close physical proximity and synchrony of flowering, are frequently met under natural conditions in these two major sorghum-growing countries in East and West Africa. However, other aspects of gene flow that need to be investigated include the outcrossing rates of wild sorghum, the fitness of crop-weed hybrids in the $F_{1}$ and successive generations, and the persistence of introgressed crop genes in these environments. Thus, further research is needed to examine the extent of spontaneous crop-towild gene flow and the ecological and evolutionary consequences of this process for wild and weedy sorghum populations in Africa.

\section{Acknowledgments}

Funding for this research was provided by the U.S. Agency for International Development through the USDA, ARS, Office of International Research Programs, and a grant from the Biodiversity and Biotechnology Initiative of the U.S. Agency for International Development.

\section{References}

Akimoto, M., Y. Shimamoto, and H. Morishima. 1999. The extinction of genetic resources of Asian wild rice, Oryza rufipogon Griff.: A case study in Thailand. Genet. Resour. Crop Evol. 46:419-425

Aldrich, P.R., and J. Doebley. 1992. Restriction fragment variation in the nuclear and chloroplast genomes of cultivated and wild sorghum bicolor. Theor. Appl. Genet. 85:293-302.

Aldrich, P.R., J. Doebley, K.F. Schertz, and A. Stec. 1992. Patterns of allozyme variation in cultivated and wild Sorghum bicolor. Theor. Appl. Genet. 85:451-460.

Arriola, P.E. 1995. Crop to weed gene flow in sorghum: Implications for transgenic release in Africa. Afr. Crop Sci. J. 3:153-160.

Arriola, P.E., and N.C. Ellstrand. 1996. Crop-to-weed gene flow in the genus sorghum (Poaceae): Spontaneous interspecific hybridization between johnsongrass, Sorghum halepense, and crop sorghum, S. bicolor. Am. J. Bot. 83:1153-1160.

Arriola, P.E., and N.C. Ellstrand. 1997. Fitness of interspecific hybrids in the genus Sorghum: Persistence of crop genes in wild populations. Ecol. Appl. 7:512-518.

Ayana, A., E. Bekele, and T. Bryngelsson. 2000. Genetic variation in wild sorghum (Sorghum bicolor ssp. vertciilliflorum (L.) Moench) germplasm from Ethiopia assessed by random amplified polymorphic DNA (RAPD). Hereditas 132:249-252.

Baum, M., E.S. Lagudah, and R. Appels. 1992. Wide crosses in cereals. Annu. Rev. Plant Physiol. Plant Mol. Biol. 43:117-143.

Bean, S., and B.P. Ioerger. 2006. Protein composition and grain hardness in sorghum. In Abstracts, World Grains Summit: Foods and Beverages, San Francisco, CA. 17-20 Sept. 2006. AACC International, St. Paul, MN.

Burke, J.M., K.A. Gardner, and L.H. Rieseberg. 2002. The potential for gene flow between cultivated and wild sunflower (Helianthus annuus) in the United States. Am. J. Bot. 89:1550-1552.

Casas, A.M., A.K. Kononowicz, T.G. Haan, L. Zhang, D.T. Tomes, R.A. Bressan, and P.M. Hasegawa. 1997. Transgenic sorghum plants obtained after microprojectile bombardment of immature inflorescences. In Vitro Cell. Dev. Biol. 33:92-100.

Casas, A.M., A.K. Kononowicz, U.B. Zehr, D.T. Tomes, J.D. Axtell, L.G. Butler, R.A. Bressan, and P.M. Hasegawa. 1993. Transgenic sorghum plants via microprojectile bombardment. Proc. Natl. Acad. Sci. USA 90:11212-11216.

Central Statistical Authority. 2004. Agricultural Sample Survey: Result on area, production and yield of major crops by sector and seasons. Statistical Bulletin. Central Statistical Authority, Addis Ababa, Ethiopia.

de Wet, J.M.J. 1978. Systematics and evolution of sorghum sect. Sorghum (Graminae). Am. J. Bot. 65:477-484.

Doebley, J. 1990. Molecular evidence for gene flow among Zea species. BioScience 40:443-448.

Doggett, H. 1988. Sorghum. 2nd ed. Tropical Agricultural Series. Longman Scientific, Essex, UK

Doggett, H. 1991. Sorghum history in relation to Ethiopia. p. 140-159. In J.M.M. Engels et al. (ed.) Plant genetic resources of Ethiopia. Cambridge Univ. Press, Cambridge, UK.

Eber, F., A.M. Chevre, A. Baranger, P. Vallee, X. Tanguy, and M. Renard. 1994. Spontaneous hybridization between a male sterile oil seed rape and two weeds. Theor. Appl. Genet. 88:362-368.

Ejeta, J., and C. Grenier. 2005. Sorghum and its weedy hybrids. p. 123-135. In J. Gressel (ed.) Crop ferality and volunteerisim. CRC Press, Boca Raton, FL. 
Ellstrand, N.C., and C.A. Hoffman. 1990. Hybridization as an avenue of escape for engineered genes. Bioscience 40:438-442.

Ellstrand, N.C., H.C. Prentice, and J.F. Hancock. 1999. Gene flow and introgression from domesticated plants into their wild relatives. Annu. Rev. Ecol. Syst. 30:539-563.

Fedak, G., and F. Han. 2005. Characterization of derivatives from wheat-Thinopyrum wide crosses. Cytogenet. Genome Res. 109:360-367.

Gao, Z., X. Xie, Y. Ling, S. Muthukrishnan, and G.H. Liang. 2005. Agrobacterium tumefaciens-mediated sorghum transformation using a mannose selection system. Plant Biotechnol. J. 3:591-599.

Giddings, G. 2000. Modeling the spread of pollen from Lolium perenne: The implications for the release of wind pollinated transgenics. Theor. Appl. Genet. 100:971-974.

Girijashankar, V., H.C. Sharma, K.K. Sharma, V. Swathisree, L.S. Prasad, B.V. Bhat, M. Royer, B.S. Secundo, M.L. Narasu, I. Altosaar, and N. Seetharama. 2005. Development of transgenic sorghum for insect resistance against the spotted stem borer (Chilo partellus). Plant Cell Rep. 24:513-522.

Gressel, J. 2005. Crop ferality and volunteerisim. CRC Press, Boca Raton, FL.

Harlan, J.R. 1992. Crops and man. ASA, Madison, WI.

Hauser, T.P., and G.K. Bjarn. 2001. Hybrids between wild and cultivated carrots in Danish carrot fields. Genet. Resour. Crop Evol. V48:499-506.

Holm, L.G., D.L. Plucknett, J.V. Poncho, and J.P. Herberger. 1977. The world's worst weeds: Distribution and biology. Univ. Press of Hawaii, Honolulu.

Howe, A., S. Shirley, I. Dweikat, M. Fromm, and T. Clemente. 2006. Rapid and reproducible Agrobacterium-mediated transformation of sorghum. Plant Cell Rep. 25:751-758.

Jenczewski, E., J. Ronfort, and A.M. Chevre. 2003. Crop to wild gene flow, introgression and possible fitness effects of transgenes. Environ. Biosafety Res. 2:9-24.

Keeler, K.H., and C.E. Turner. 1990. Management of transgenic plants in the environment. p. 189-218. In M. Levin and H. Strauss (ed.) Risk assessment in genetic engineering: Environmental release of organisms. McGraw-Hill, New York.

Krishnaveni, S., J.-M. Jeoung, S. Muthukrishnan, and G.H. Liang. 2001. Transgenic sorghum plants constitutively expressing a rice chitinase gene show improved resistance to stalk rot. J. Genet. Breed. 55:151-158.

Morrell, P.L., T.D. Williams-Coplin, A.L. Lattu, J.E. Bowers, J.M. Chandler, and A.H. Paterson. 2005. Crop-to-weed introgression has impacted allelic composition of johnsongrass populations with and without recent exposure to cultivated sorghum.
Mol. Ecol. 14:2143-2154.

National Meteorological Services Agency. 1996. Climate and agroclimatic resources of Ethiopia. p. 137. Meteorological Research Report Series. Vol. 1, no. 1. National Meteorological Services Agency, Addis Ababa, Ethiopia.

Pandey, R.K., J.W. Maranville, and T.W. Crawford, Jr. 2001. Agriculture intensification and ecologically sustainable land use system in Niger: Transition from traditional to technologically sound practices. J. Sustain. Agric. 19:5-24.

Paterson, A.H., K.F. Schertz, Y.R. Lin, S.C. Liu, and Y.L. Chang. 1995. The weediness of wild plants: Molecular analysis of genes influencing dispersal and persistence of johnsongrass, Sorghum halepense (L.) Pers. Proc. Natl. Acad. Sci. USA 92:6127-6131.

Reagon, M.R., and A.A. Snow. 2006. Cultivated Helianthus annuus (Asteraceae) volunteers as a genetic "bridge" to weedy sunflower populations in North America. Am. J. Bot. 93:127-133.

Rick, C.M., J.W. DeVera, R.T. Chetelat, and M.A. Stevens. 1987. Potential contribution of wide crosses to improvement of processing tomatoes. Acta Hortic. 200:45-56.

Sangduen, J., and W.W. Hanna. 1984. Chromosome and fertility studies on reciprocal crosses between two species of auto-tetraploid sorghum, Sorghum bicolor (L.) Moench. and S. halepense (L.) Pers. J. Hered. 75:293-296.

SAS Institute. 2005. Statistical analysis systems: Release version 9.1. SAS Inst., Cary, NC.

Schmidt, M., and G. Bothma. 2006. Risk assessment for transgenic sorghum in Africa: Crop-to-crop gene flow in Sorghum bicolor (L.) Moench. Crop Sci. 46:790-798.

Snow, A.A., D. Pilson, L.H. Rieseberg, M. Paulsen, N. Pleskac, M.R. Reagon, D.E. Wolf, and S.M. Selbo. 2003. A Bt transgene reduces herbivory and enhances fecundity in wild sunflowers. Ecol. Appl. 13:279-286.

Wilkes, H.G. 1977. Hybridization of maize and teosinte in Mexico and Guatemala and the improvement of maize. Econ. Bot. 31:254-293.

Zaharieva, M., and P. Monneveux. 2006. Spontaneous hybridization between bread wheat (Triticum aestivum L.) and its wild relatives in Europe. Crop Sci. 46:512-527.

Zhao, Z.-Y., T. Cai, L. Tagliani, N. Wang, H. Pang, M. Rudert, S. Schroeder, D. Hondred, J. Seltzer, and D. Pierce. 2000. Agrobacterium-mediated sorghum transformation. Plant Mol. Biol. 44:789-798.

Zhu, H., Krishnaveni, G.H. Liang, and S. Muthukrishnan. 1998. Biolistic transformation of sorghum using a rice chitinase gene. J. Genet. Breed. 52:243-252. 